\title{
Trade, Aid, Remittances and Migration
}

By

\author{
Sule Akkoyunlu*
}

August 2007

\begin{abstract}
We investigated whether migration is interrelated with trade, aid and remittances so that any policies that consider trade, aid and remittances also affect the decision to migrate. We developed and estimated an empirical model of Turkish migration to Germany and tested the model for the 1969-2004, using the cointegration technique. A single cointegrating vector is found among the gross migration inflows and the following explanatory variables: the relative income ratio between Germany and Turkey, the unemployment rates in Germany and Turkey, aid, the trade intensity variable and the ratio of manufacturing exports with Germany to total exports with Germany and remittances as a ratio of Turkish GDP. The results of this study show that migration, trade, aid and remittances are interrelated, however, migration will be better managed when the dynamic gains from trade and aid are considered. Hence, the broad-based and rapid economic development with increase in income is the only effective means of reducing migration pressures in a labour-surplus country. This is mainly because the income differential is the most significant factor in determining migration flows.
\end{abstract}

Keywords: Trade; Aid; Remittances; Migration; Cointegration

JEL Classification: C22; F16; F22; F24; F35

The research reported in this paper was financially supported by the European Union within the context of the FEMISE program. The contents of this paper are the sole responsibility of the authors and do not reflect the opinion of the European Union.

* Department of Economics, Bilkent University; DIW Berlin. Email: sakkoyunlu@diw.de 


\section{Introduction}

In the traditional trade models, both trade and international factor mobility are driven by differences in factor proportions between countries. Countries with a high ratio of capital to labor will export capital-intensive goods, import labor-intensive goods, invest in abroad and will be attractive for migration. Trade in goods in these models will reduce the incentive for factor movements and will lead the exact equalization of factor prices across countries. Thus, international trade narrows the wage gap and reduces the incentives to migrate. The feared resumption of massive labor flows from Turkey with the recognition of Turkey as a candidate for accession at the Helsinki European Council in December 1999 and the start of accession negotiations between European Union and Turkey in October 2005, brings back the question that whether the trade policy can be effective in reducing migration pressure from Turkey. Thus, can we have an optimal combination of trade, aid, remittance and migration policies in order to avoid massive labor inflows from Turkey with the accession? This proposition might be attractive for the receiving countries because the movements of goods and services between countries through trade is more welcomed than the movements of people due to the additional fiscal burdens that migrants put on others and these external costs can create social tension. Thus, by exporting labor-intensive goods Turkey in effect export labor embodied in its export and hence there will be no need for migration in this approach. More importantly, if trade substantially reduce unemployment and contribute to the economic growth as well as economic efficiency then it can really help reduce the pressures for migration. Thus, trade is not only exchange of goods but promotes competition and investment in education and infrastructure, creates an opportunity to exploit economies of scale, transfer of knowledge and technology. Therefore, the dynamic rather than static effect of trade can be more effective in reducing the income differential that is the main driving force of migration.

Although rich countries protect most strongly the sectors that produce competing laborintensive goods, Turkish trade with Germany has been in favour of Turkey. Turkey took two major trade liberalizing policies: in the early 1980s and the Customs Union 
Agreement in 1996. The export-led growth strategy was accompanied by gradual import liberalization, more flexible exchange rate regime and more effective export incentive programmes. These reforms not only rapidly expanded total volume of exports but also the export decomposition changed in favour of manufacturing goods that Turkey has a comparative advantage. Furthermore, following trade liberalization investment, employment and output in manufacturing sector increased, although the real wage growth in manufacturing sector has been very modest, TSI (2005). Hence, the share of manufacturing exports in total exports in which Turkey has a comparative advantage may have an important deterrent factor in determination of migration flows.

Development aid that speeds up economic development and human capital formation also helps to keep the population at home. Investment in human capital results in higher productivity that is translated into increasing returns to scale effect and labor productivity increases countinously. Remittances, likewise if are used for productive investment at home can create employment and contribute to economic growth. However, economic growth and increase in income are likely to increase migration pressure in the short-run by making migration accessible to unskilled migrants with low incomes and low access to credit markets. Thus, labor mobility tends to interact closely with trade, aid, and capital flows in many ways direct and indirect. These inter-linkages have special importance in relation to current and anticipated inflows of Turkish migrants to Germany. Therefore, revised policies based on the study of these linkages can make migration more manageable and promote efficiency in the region. This is especially important if we consider migration not only economic but also social phenomenon.

To our knowledge, this is the only empirical study that incorporates trade, aid and remittances in a migration model in order to consider the extent to which trade, aid and remittance policies can be effective in managing migration inflows.

The paper structured as follows. Section 2 gives background information on how trade, aid, remittances and migration are interrelated. Section 3 considers the empirical model. Section 4 provides the econometrics results. Section 5 concludes. 


\section{Background}

Trade liberalization aims not only access to foreign markets to sell goods but also to speed up economic growth. However, international trade agreements have been unsuccessful in promoting growth in poor countries such as NAFTA. Stiglitz (2006) argues that NAFTA did not bring benefits to Mexico, but lowered wages and increased unemployment. This was because trade agreements have been asymmetric, and this put developing countries at a disadvantage. In addition, a lack of infrastructure in developing countries prevents them to bring their goods to markets. Likewise, imperfect capital markets prevent them to get the necessary finance for new export opportunities. Trade liberalization when done fairly, when accompanied by the right measures and the right policies help development. In this process, aid certainly has an important role to increase trade by providing the infrastructure. NAFTA had the aim that it would help close the gap in income between Mexico and the United States and thus reduce the pressure of illegal migration. However, NAFTA did not result in a rapid growth in Mexico's economy. This was because trade liberalization was so fast that private sector could not create jobs immediately, and further high interest rates prevented them create new jobs. It needs to be added that, in so far as increased imports to migrant sending countries may drive out local firms from the market, thus eliminating jobs directly or indirectly linked to them, liberalized trade may contribute to increase pressures for migration during the transition. However, any such job losses in the short-run should be outweighed by additional employment created in the labour-intensive export sector, combining economies of scale, easier and less expensive supply of imports as production inputs and a more efficient allocation of resources throughout the economy in the long-run.

In traditional model factor price equalization holds so that wages of skilled workers, of unskilled workers and the return to capital will be the same in everywhere. Trade liberalization leads toward the equalization of factor prices. Free trade is a substitute for people having to move. Furthermore, if labor moves from a labor abundant country where productivity and wages are low to one where labor is scare where wages are high, 
then output will increase and economy will grow. However, economic growth in the labor abundant country will depend on how fast they acquire the knowledge and technology that the advanced countries have. Thus, wages will only rise if productivity increase and this will depend on the investment on technology and education.

Turkey has a comparative advantage in production of agricultural and textile goods (that are labor-intensive goods) and reduction in tariffs and restrictions of these products with the European countries may reduce migration in the long-run. However, in the short-run the effect may be positive. The exports of manufacturing goods to Germany certainly helped Turkey's transition from the agriculture dominated economy. Over the years following trade liberalization employment, exports and output of manufacturing sector have increased.

However, even if all tariff and trade barriers are reduced to zero the wage differences between Turkey and Germany will not equalize. This is not only related to the transportation costs, but the economic structure of Turkey. The wage differences will persist unless there are capital flows to Turkey that will make workers more productive and the gap in knowledge between the West and Turkey is eliminated. It will take longer time than the period under investigation in this study to eliminate the knowledge gap and the capital shortage in Turkey. However, in this study we show that the increase of exports of goods that Turkey has a comparative advantage can reduce migration pressure in the long-run. Therefore, fair trade regime has an important role to play. However, the most important impacts of trade liberalization would be its help to alleviate poverty through job creation, promoting competition, improvements in education and in health and technological learning.

Aid $^{1}$ or official development assistance (ODA) is not only the transfer of funds that combines loans and grants but also the provision of technical assistance or capacity building. It should be emphasized that a loan is called aid if only it carries a subsidy element. However, aid will only help if they introduce ideas and improve practices that

\footnotetext{
${ }^{1}$ Aid in this paper refers to the official development assistance (ODA).
} 
increase the overall size of the resources available for growth and poverty reduction. Therefore, aid is most welcomed when it is accompanied with ideas, policies and capacity building. Only then aid can contribute to the long-run economic growth and eliminate wage differences between Turkey and the west. However, the share of "short impact” aid to Turkey such as budget and balance of payments support, infrastructure investments is higher than the share of aid for productive sectors such as agriculture and industry, see Uygur (1992) and OECD (2007). In the 1960s and 1970s, aid was used to finance investments in the manufacturing sector, but in the 1980s and 1990s, aid was used to greater extent to finance the interest bills, principal repayments and trade deficits as well as investment in energy and infrastructure. Thus, a relative neglect of industrial investments can make aid detrimental to long-run economic growth and employment creation. Needless to mention Turkish economic and social policies and governance as well as the institutions affect project qualities.

Aid and trade are viewed as substitute for one another and trade is the favoured of the two. The role of trade in economic growth and poverty alleviation might be more effective than aid, given the structure, type and the magnitude of aid. Exports growth can certainly generate incomes for the poor, as many unskilled would-be migrants as in the Turkish case are unable to finance their migration cost out of their low-wage income. The increase of migration with trade liberalization in the short-run has been called a migration hump, see Martin and Taylor (1996). This means that the same economic policy that reduces migration in the long-run can increase it in the short-run, making free trade policy a dilemma as the best way to reduce migration.

\section{An empirical model}

We model Turkish migration to Germany as follows: 


$$
\begin{aligned}
\ln M_{t}= & \alpha_{0}+\alpha_{1} \ln \left(Y_{f t} / Y_{h t}\right)+\alpha_{2} U_{f t}+\alpha_{3} U_{h t}+\alpha_{4} \ln \left(\frac{A_{t}}{G N I_{t}}\right)+\alpha_{4} \ln T_{t} \\
& +\alpha_{5} \ln \left(\frac{M X G_{t}}{T X G_{t}}\right)+\alpha_{6} \ln \left(\frac{R_{t}}{Y_{h t}}\right)+\varepsilon_{t}
\end{aligned}
$$

In (1), $\ln M_{t}$ denotes the log of the gross inflow of Turkish migrants to Germany, expressed as a share of the home population. Brücker and Schröder (2006) argue that migration stocks, rather than the (net) migration rate, should be used in migration estimation, since an equilibrium relationship between migration stocks and the explanatory variables arises in the long run, while the net flows tend to zero. However, in this study we use the gross migration rate (as is done, for example, in Borjas (1987, 1999), Hatton (1995), Clark et al. (2002), Pedersen et al. (2006), Péridy (2006), and Mayda (2007)), not the stock of Turkish migrants. We test several hypotheses such that trade and aid flows reduce incentive to migrate and remittances trigger additional migration. Typically, migrants of different cohorts exhibit different remittance behaviour. For example, migrants tend to pay the debt that they incurred in financing their migration during the first year or so following their migration, and over time, upon bringing their families to Germany, they remit less than more recent migrants. This implies different remittance behavior for the cohorts that sum up to the stock of Turkish migrants. Therefore, we use as the dependent variable the gross migration rate rather than stocks or net inflows. In addition, as explained below, we incorporate the share of manufacturing exports to Germany in total exports to Germany and the trade intensity as independent variables, which require us to work with flows rather than with the stock of migrants. Notably, the initial data analysis did not provide evidence of any significant relationship between the stocks and the explanatory variables, especially not between the stocks and workers' remittances, the export and the trade intensity variable.

The $\ln \left(Y_{f t} / Y_{h t}\right)$ is the log of the income in the host country divided by the income in the home country, measured as per capita GDP in purchasing power parity terms. This variable captures the pecuniary incentive to migrate that arises from the income differential. 
$U_{f t}$ is the unemployment rate in Germany. The German migration policies have become more restrictive during periods of high unemployment in Germany (Mayda and Patel (2004)).

The $U_{h t}$ term is the unemployment rate in Turkey. It represents a simple push factor. The unemployment rate enters the empirical model individually rather than as a difference term, in line with (for example) Borjas (1987, 1999), Hatton (1995), Clark et al. (2002), Pedersen et al. (2006), Péridy (2006), and Mayda (2007).

$\ln \left(\frac{A_{t}}{G N I_{t}}\right)$ is the overseas development aid to GNI ratio. The hypothesis is that aid will encourage economic development and will reduce incentive to migrate.

$\ln T_{t}$ is a proxy for the intensity of economic cooperation between Turkey and Germany, calculated as the log of the share of the trade volume (sum of exports and imports) between the two countries in the total trade volume of Turkey with all its trading partners. The volume of trade between two economies could measure a variety of links between the economies. The higher the volume, the more intensive the links. The bilateral links co-shape the migration "infrastructure" or environment. It stands to reason that an increase in the total volume of trade between Germany and Turkey can alleviate the financial and informational constraints associated with migration from Turkey to Germany, and thereby lower the cost of migration, particularly for low-skill workers with low incomes and with limited access to credit markets. Trade can serve as an indicator of the level of business linkages between economies, which in turn lower informational costs and reduce uncertainty, thereby impinging on the migration "climate." In addition, trade could impact on migration in more subtle ways. When the volume of trade between Turkey and Germany is high, Turkey will be less likely to allow appreciation of its currency - exporters could suffer greatly if it did - and is more likely to tilt in the direction of depreciation of its currency. For a given stock of Turkish migrants in 
Germany, a depreciation of the Turkish currency could prompt migrants to increase their remittances.

$\ln \left(\frac{M X G_{t}}{T X G_{t}}\right)$ is the share of Turkish manufacturing exports with Germany in total Turkish exports with Germany. This variable captures the effects of the expansion of manufacturing exports that Turkey has a comparative advantage on decision to migrate. In other words, with this variable we test whether trade and migration are substitutes or complements.

Finally, $\ln \left(\frac{R_{t}}{Y_{h t}}\right)$ is the log of the ratio between workers' remittances and Turkish GDP.

The data on workers' remittances were obtained from the balance sheets of the Bundesbank, while the data on the per capita GDP of Germany and of Turkey were obtained from the OECD. Data on Turkish unemployment, population, and trade were gathered from the Turkish Institute of Statistics. Data on Turkish migration and on German unemployment were obtained from the Federal Statistical Office in Germany. Data on aid is obtained from the World Development Indicators, World Bank.

\section{The general to specific approach and econometrics results}

Modelling based on the general-to-specific modeling approach that aims to build empirical models that economically sensible and statistically satisfactory, Hendry (1995), Campos and Ericsson (1999) and Hoover and Perez (1999). Although we have thirty-six years of annual data, as shown in Akkoyunlu (1999) and Campos and Ericsson (1999), the sample size is only one of several factors which determine how much information is in the sample. Even our data sample is small, the data movements so large that are crucial for the information of data. Therefore, over-parameterisation should not be a concern. 
Therefore, we start with a general model which is probably over-parameterised with two lags for the gross inflows of Turkish migrants to Germany, expressed as the share of the home population, $\ln M_{t}$ and a broad set of explanatory variables (income differential (the ratio of German GDP to Turkish GDP in PPPs, $\ln \left(\frac{Y_{f t}}{Y_{h t}}\right)$, the German unemployment rate, $U_{f t}$, the Turkish unemployment rate, $U_{h t}$, aid (aid to GNI ratio, $\ln \left(\frac{A_{t}}{G N I_{t}}\right)$ ), trade intensity (the share of total trade with Germany in total Turkish trade, $\ln T_{t}$ ), the share of Turkish manufacturing exports with Germany in total Turkish exports with Germany, $\ln \left(\frac{M X G_{t}}{T X G_{t}}\right)$, and Turkish remittances from Germany, expressed as a ratio to Turkish GDP, $\left.\ln \left(\frac{R_{t}}{Y_{h t}}\right)\right)^{2}{ }^{2}$ Thus, we allow for everything ${ }^{3}$ at the outset that might be significant and then investigate whether and how this initial general model can be reduced without significant loss of information about the parameters of interests. Economic theory information helps specify the vector of parameters of interest; however, the parameters of interest might come from a data-instigated model. However, theory consistency is essential, so that there is no evaluation conflict between the model and the theory interpretation. Hence, I aim to conclude with a parsimonious model which has orthogonal regressors as well as satisfying the necessary conditions for both congruence and encompassing.

However, the general-to-specific modelling still suffers from allegations that it mines the data pejoratively. These allegations are, as in Campos and Ericsson (1999):

I. Repeated Testing: Regressors are selected in an attempt to maximise $t$-ratios. Thus simply conducting multiple tests will induce significant outcomes by chance.

\footnotetext{
${ }^{2}$ All the variables apart from the unemployment rates are expressed in logs.

${ }^{3}$ Social networks are considered to be and found in many studies to be an important determinant of migration as they can provide information prior to migration, and financial assistance and support until the migrants get used to the new environment. However, in this study we found the stock of Turkish migrants that represents social networks to be insignificant in the short- as well as in the long-run.
} 
II. Data Interdependence: Non-constant coefficient might result due to an omitted regressor that is correlated with the included one, and this correlation changes over time due to regime changes that generate the system.

III. Corroboration: The regressors are chosen according to a criterion such as having sensible coefficient estimates. However, there might still be important omitted variables.

IV. Over-parameterization: If the model is over-fitted, it uses up many degrees of freedom.

However, this paper, during the building process of the empirical model, shows that these allegations can be refuted easily.

The annual data covers the period from 1969-2004 (see Figure 1, for the basic properties of the data).

Our first step is to obtain parsimonious unrestricted model, which is quite challenge given the relatively small number of observations $(T=36)$ compared to the number of explanatory variables $(k=7)$. The results of the unrestricted general model are given in Table 1. Table 1 shows that the unrestricted model can adequately describe the data, since the misspecification tests show no serious departures from the underlying model assumptions.

The next step is to find the cointegrating relationship between variables. The solved long run equation, as well as the error correction mechanism (ECM) is given below. The test on the significance of the lag length suggests that the model should have two lags. 


$$
\begin{aligned}
& \ln M_{t}=-18.927+4.858 \ln \left(\frac{Y_{f t}}{Y_{h t}}\right)-0.034 U_{f t}+0.229 U_{h t} \\
& \begin{array}{lllll}
(\mathrm{SE}) & (3.004) \quad(1.852) & (0.042) & (0.044)
\end{array} \\
& -0.055 \ln \left(\frac{A_{t}}{G N I_{t}}\right)+2.327 \ln T_{t}-0.679 \ln \left(\frac{M X G_{t}}{T X G_{t}}\right) \\
& \begin{array}{llll}
(\mathrm{SE}) & (0.053) \quad(0.362) & (0.195)
\end{array} \\
& +0.743 \ln \left(\frac{R_{t}}{Y_{h t}}\right) \\
& \text { (SE) } \quad(0.119) \\
& \mathrm{ECM}=\ln M_{t}+18.927-4.858 * \ln \left(\frac{Y_{f t}}{Y_{h t}}\right)+0.034{ }^{*} U_{f t}-0.229 * U_{h t} \\
& +0.055 * \ln \left(\frac{A_{t}}{G N I_{t}}\right)-2.327 * \ln T_{t}+0.679 * \ln \left(\frac{M X G_{t}}{T X G_{t}}\right) \\
& -0.743 \ln \left(\frac{R_{t}}{Y_{h t}}\right) \\
& \text { WALD test } \chi^{2}(7)=1210.27[0.00] * *
\end{aligned}
$$

\section{Tests on the significance of each lag}

Lag

\begin{tabular}{ll}
1 & $F(8,10)=10.13[0.00] * *$ \\
2 & $F(8,10)=9.88[0.00] * *$ \\
\hline
\end{tabular}

\section{Tests on the significance of all lags up to 2 Lag \\ $1-2$ \\ $F(16,10)=9.88[0.00] * *$ \\ 2- 2

$F(8,10)=13.89[0.00]$ * *

It is immediately clear that this set cointegrates. ${ }^{4}$ The solved long run equation represents the cointegrating vector that enters in the conditional model as the error correction term.

\footnotetext{
${ }^{4}$ The graphics, regression output and residual diagnostic tests were all calculated using GiveWin 2.2, PcGive 10.2 and Pc-Gets 1.2, see Doornik and Hendry (2001a,b,c).
} 
In the long run equation, relative income, the unemployment rate in Turkey, the trade intensity, and workers' remittances contribute positively to migration from Turkey, while unemployment in Germany, aid and the share of manufacturing exports to Germany in total exports to Germany contribute negatively to migration from Turkey to Germany. The unemployment rate in Germany and aid are not significant in the long-run equation, but we keep unemployment rate in Germany for further analysis as there is a strong theoretical argument for its presence in the migration equation. We also keep aid for the further analysis as aid might be more significant in the short-run compared to the longrun due its structure, type and magnitude. In the long-run, income differential and trade intensity are the most significant variables in explaining migration flows from Turkey to Germany. Thus, a 10 percent increase in income differential increases the gross migration inflows by 48.58 percentage points, a very significant effect. Likewise, a 10 percent increase in trade intensity increases the gross migration inflows by 23.27 percentage points, a large effect. In addition, the sign on the share of manufacturing exports with Germany to total exports with Germany suggests that trade and migration are substitutes in the long-run. It is together with remittances are the important determinants of migration inflows in the long-run, after the income differential and the trade intensity.

There are a few steps in the reduction of the final (conditional) model from the above general specification and these reductions are done automatically with Pc-Gets ${ }^{5}$ (the corresponding standard errors and $t$-ratios reported in parentheses below the coefficient estimates).

$$
\begin{aligned}
& \Delta \ln M_{t}=0.043+0.206 \Delta \ln M_{t-1}+1.936 \Delta \ln \left(\frac{Y_{f t}}{Y_{h t}}\right)-0.093 \Delta U_{f t} \\
& \begin{array}{lll}
(0.019)(0.082) & (0.486) & (0.026)
\end{array} \\
& {[2.23][2.51] \quad[3.98] \quad[-3.53]} \\
& -0.093 \Delta U_{f t-1}-0.039 \Delta \ln \left(\frac{A_{t}}{G N I_{t}}\right)_{-1}+0.510 \Delta \ln \left(\frac{M X G_{t}}{T X G_{t}}\right)_{-1} \\
& \begin{array}{lrr}
(0.031) & (0.017) & (0.128)
\end{array} \\
& {[-3.00] \quad[-2.37] \quad[3.99]}
\end{aligned}
$$

\footnotetext{
${ }^{5}$ The corresponding standard errors reported in parentheses below the coefficient estimates.
} 


$$
\begin{aligned}
& +0.126 \Delta \Delta U_{h t}+0.333 \Delta \Delta \ln \left(\frac{R_{t}}{Y_{h t}}\right)-0.733 \mathrm{ecm}_{t-1} \\
& \begin{array}{lll}
(0.025) & (0.068) & (0.069)
\end{array} \\
& {[4.96] \quad[4.86] \quad[-10.60]} \\
& R^{2}=0.919 \mathrm{~F}(9,24)=30.36[0.00] \hat{\sigma}=0.094 \mathrm{DW}=1.96 \\
& \text { RSS }=0.2109 \text { for } 10 \text { variables and } 34 \text { observations } \\
& F_{\text {ar }}(2,22)=3.389[0.05] F_{\text {arch }}(1,22)=1.214[0.28] \\
& \chi_{\text {nd }}^{2}(2)=0.37[0.83] F_{\text {hetero }}(18,5)=0.33[0.96] \\
& F_{\text {reset }}(1,23)=1.75[0.20] \mathrm{T}=34(1971-2004)
\end{aligned}
$$

The conditional model (equation (4)) is parsiomonious. The diagnostic tests are satisfactory, hence, the conditional model satisfies the design criteria. The data generating process (DGP) as a model satisfies the design criteria suggesting that the general-to-specific modelling is successful in creating a model that mimics the properties of DGP. The error-correction term is highly significant and has the expected sign. Figure 2 shows the actual and fitted values of the final model. The graphs show how well the final model explains the data and the residuals uncorrelated and normally distributed.

Income differential is the most important determinant of migration flows in the short-run also: a 10 percent increase in the change in income differential will increase the change in migration inflows almost by 20 percent. This suggests that until the income gap is reduced, the pressure to migrate will remain. However, the high unemployment rate at home, sustains less strong pressure to migrate. The availability of jobs in Germany strongly matters in the short-run. The share of manufacturing exports with Germany in total exports to Germany increases migration flows in the short-run that can be interpreted with the migration hump. Thus, increase in income due to exports might make some unskilled with low income workers to afford the cost of migration. In addition, the displacement and disruptions that accompany development temporarily can also increase migration. 
Aid policy only effective in reducing migration flows in the short-run, but this effect is small. Hence, financial assistance is not a durable long-run solution to reduce migration pressure. However, if aid are conditional on good policies and has a higher share of technical assistance and training that would transfer expertise and know-how and increase in investment in productive sectors and hence help human capital development, and accelerate job creation and economic growth so that income differences between Turkey and Germany is reduced, only then aid policies can have a long-lasting effect.

Remittances are found to significantly explain migration in the short-run as well as in the long-run. The results support the hypothesis that remittances fuel migration. It is normally hypothesized that remittances by providing capital in the home countries, promote investment and help create jobs and reduce the incentive to emigrate. However, in this study we found that remittances to an economy are the harbinger of migration from the economy. Liquidity constraints, signalling, portfolio revision, and other considerations raise the possibility that an economy that receives more remittances will generate more migration, Akkoyunlu et al. (2007). The results show that both push and pull factors matter in determining Turkish migration inflows to Germany.

Figures 3, 4 and 5 plot the recursive estimates for the coefficients on the constant term, $\Delta \ln M_{t-1}, \quad \Delta \ln \left(\frac{Y_{f t}}{Y_{h t}}\right), \quad \Delta U_{f t}, \quad \Delta U_{f t-1}, \quad \Delta \ln \left(\frac{A_{t}}{G N I_{t}}\right)_{-1}, \quad \Delta \ln \left(\frac{M X G_{t}}{T X G_{t}}\right)_{-1}, \Delta \Delta U_{h t}$, $\Delta \Delta \ln \left(\frac{R_{t}}{Y_{h t}}\right)$, and $e c m_{t-1}$; their respective $t$-ratios; and the recursive residual sum of squares, one-step residuals, one-step Chow statistics, and break-point Chow statistics, respectively. Constant coefficients in Figure 3 in the presence of the large variations in the marginal process such as unemployment rates imply super exogenous variables that counter the second sense of data mining. Further, the recursive t-ratios in Figure 4, increase in absolute value as the sample size increases countering the first sense of data mining. Hence, the nominal critical levels of test statistics are not affected. Even with thirty-four observations and ten variables in the final model $t$-ratios are greater than three in magnitude suggesting that over-parameterisation is not a concern given information 
content in the data and refuting the fourth sense of data mining. Figure 5 shows that the recursive residual sum of squares increase over time and the recursive estimate of standard error $\hat{\sigma}_{t}$ declines over time rather than increase, hence countering the first sense of data mining.

\section{Conclusions}

We investigated whether migration is interrelated with trade, aid and remittances so that any policies that consider trade, aid and remittances also affect the decision to migrate. We developed and estimated an empirical model of Turkish migration to Germany and tested the model for the 1969-2004, using the cointegration technique. A single cointegrating vector is found among the gross migration inflows and the following explanatory variables: the relative income ratio between Germany and Turkey, the unemployment rates in Germany and Turkey, aid, the trade intensity variable and the ratio of manufacturing exports with Germany to total exports with Germany and remittances as a ratio of Turkish GDP. Based on the results of the cointegration analysis, a parsimonious single equation conditional error-correction model is developed. That is both congruent and parsimoniously encompasses the general model. The residuals are also innovations against the available information. The results further support the view that a constructive data mining qua general-to-specific modelling approach is productive as it has a high probability of locating the DGP.

The results show that migration is interrelated with trade, aid and remittances. However, the best way to manage economic migration is to generate rapid economic growth with productive employment opportunities and therefore to raise incomes in the country of origin.

Until the income differential converges to zero the migration pressure will persists, and it would go on until relative wages in Turkey rises sufficiently. Trade policy that would 
bring jobs to Turkey has a role to play in the long-run, but in the short-run will increase migration. In addition, aid is significant only in the short-run for reducing migration inflows. This might be associated with its small magnitude and its high volatility. Levels of development assistance indeed are small and declining compared with other financial flows such as remittances. Development aid takes the form of financial assistance and technical cooperation. The first concerns provision of finance in the form of grants and credits, the latter is the availability of professional exports to developing countries. The majority of foreign assistance to Turkey takes the form of grants and credits. Most of these loans are used for investments in the physical infrastructure such as energy, communications, transport and community services rather than in productive sectors such as education, agriculture and industry. However, aid that contributes to poverty alleviation through employment creation, human capital formation and income generation can only dampen the pressures to migrate.

For given unemployment differentials, a high level of unemployment in Germany reduces migration so that employment opportunities matters greatly in the destination for migration. However, employment opportunities at home also have a role in the short- as well as in the long-run. Hence, creating more employment opportunities and better conditions of work will also reduce migration pressure.

The results are consistent with Akkoyunlu et al. (2007) that remittances are harbinger of migration from Turkey so that liquidity constraints, signaling, portfolio revision and other considerations raises the possibility that an economy that receives more remittances would generate more migration.

Fair trade policy help reduce the incentives for migration, but it is certainly not enough to eliminate these incentives. Furthermore, the aid should be available only if the right policies are adhered to so that any structural aid from the European Commission during the accession period should have a strict conditionality element. Aid in magnitude has also been very small, and an increase its magnitude will have a significant impact. 
The results show that the choice is not trade or aid for reducing migration pressure, but aid and trade. Trade and aid jointly have a role to play especially in the short run, when trade increases migration, aid reduces migration pressure. Thus, the right combination of trade and aid policies can help manage the labor inflows in the short-run. Germany should remain open to Turkish manufacturing goods that are mainly labor-intensive. Furthermore, aid should be used to increase the capacity of Turkey (manufacturing industry) to produce goods for exports.

The results of this study show that migration, trade, aid and remittances are related, however, migration will be better managed when the dynamic gains from trade and aid are considered. Hence, the broad-based and rapid economic development with increase in income is the only effective means of reducing migration pressures in a labour-surplus country. If the Turkish economy grows at a rate fast enough so as to cause a fall in unemployment, real wages are likely to increase. Wages and incomes will also rise to the extent that economic growth entails an upgrading of skills, knowledge and technology. Thus, economic development can affect migration by making the 'push' factors less powerful in the home country, while reducing the relative attractiveness of the potential host country. However, even rapid economic growth in Turkey will not enable them to catch up with Germany for many decades. This makes the research on Turkish migration to Germany an important topic in the coming years.

\section{References}

Akkoyunlu, S. (1999). Turkish Consumption and Saving. DPhil Thesis. University of Oxford.

Borjas, G. (1987). Self selection and the earnings of immigrants. American Economic Review 77: 531-553. 
Borjas, G. (1999). The Economic analysis of immigration. In: Handbook of Labour Economics, chapter 28, pages 1697-1760. In O. Ashenfelter and D. Card eds. NorthHolland Elsevier Science: Amsterdam.

Brücker, H. and P. J. H. Schröder (2006). International migration with heteregeneous agents: Theory and evidence. IZA Discussion Paper 2049.

Campos, J. and Ericsson N. R. (1999). Constructive Data Mining: Modelling of Consumers’ Expenditure in Venezuela. Econometrics Journal 5: 226-240.

Clark, X., T. J. Hatton, and J. G. Williamson (2002). Explaining US immigration, 19711998. Centre for Economic Policy Research Discussion Paper 453.

Doornik, J. A. and H. Hansen (1994). An omnibus test for univariate and multivariate normality. Nuffield College Discussion Paper W4\&91.

Doornik, J. A. and D. F. Hendry (2001a). GiveWin: An Interface to Empirical Modelling. Timberlake Consultants Press: London.

Doornik, J. A. and D. F. Hendry (2001b). Modelling Dynamic Systems Using PcGive, Volume II. Timberlake Consultants Press: London.

Doornik, J. A. and D. F. Hendry (2001c). Automatic Econometrics Model Selection Using PcGets. Timberlake Consultants Press: London.

Engle, R. F. (1982). Autoregressive conditional heteroscedasticity with estimates of the variance of United Kingdom inflation. Econometrica 50: 987-1007.

R. F. Engle, R. F., D. F. Hendry and J.-F. Richard (1983). Exogeneity. Econometrica 51: 277-304. 
Godfrey, L. G. (1978). Testing for higher order serial correlation in regression equations when the regressors include lagged dependent variables. Econometrica 46: 1303-1313.

Hatton, T. J. (1995). A model of UK migration, 1870-1913. Review of Economics and Statistics 77: 407-415.

Hendry, D. F. (1995). Dynamic Econometrics: Advanced Texts in Econometrics. Oxford University Press: Oxford

Hoover, K. D., and Perez, S. J. (1999). Data Mining Reconsidered: Encompassing and the General-to-Specific Approach to Specification Search. Econometric Journal 2: 167191.

Mayda, A. M. (2007). International migration: a panel data analysis of the determinants of bilateral flows. CREAM Discussion Paper 07/07.

Martin, P. and J. E. Taylor (1996). "The Anatomy of a Migration Hump". In Development Strategy, Employment and Migration: Insights from Models. J. E. Taylor ed, pp: 43-62. OECD: Paris.

Mayda, A. M. and K. Patel (2004). OECD countries migration policies changes. Appendix to International migration: A panel anaysis of economic and non-economic determinants. http//www.georgetown.edu/faculty/amm23/.

OECD (2007). The DAC Journal. OECD: Paris.

Pedersen, P. J., M. Pytlikova, and N. Smith (2006). Migration into OECD countries 1990-2000. In: Immigration and the transformation of Europe. C. A. Parsons and T. M. Smeeding eds. Cambridge University Press: New York. 
Péridy, N. (2006). Welfare magnets, border effects or policy regulations: What determinants drive migration flows into the EU. University of Nantes, mimeo.

Ramsey, J. B. (1969). Tests for specification errors in classical linear least squares regression analysis. Journal of the Royal Statistical Society, B, 31:350-371.

Stiglitz, J. E. (2006). Making globalisation work. Norton: New York.

TSI (2005). Statistical Indicators (1923-2004). Ankara.

Uygur, E. (1992), International migration for employment. Foreign aid as a means to reduce emigration: the case of Turkey. World employment programme research working paper, MIG WP 64.

White, H. (1980). A heteroscedastic-consistent covariance matrix estimator and a direct test for heteroscedasticity. Econometrica 48: 817-838.

Table 1: Least squares estimates of the unrestricted gross inflows of Turkish migrants to Germany, $\ln M_{t}$ (Equation 1):

\begin{tabular}{|c|c|c|c|c|c|c|}
\hline$\overline{\operatorname{Lag} j}$ & $\odot$ & & 1 & & 2 & \\
\hline Variables & & {$[\mathrm{t}]$} & & {$[t]$} & & {$[t]$} \\
\hline Constant & $\begin{array}{r}-17.903 \\
(2.528)\end{array}$ & {$[7.08]$} & & & & \\
\hline $\ln M_{t-j}$ & 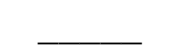 & & 0.283 & & -0.229 & \\
\hline & & & $(0.137)$ & {$[2.07]$} & $(0.139)$ & {$[-1.64]$} \\
\hline $\ln \left(\frac{Y_{f}}{V}\right)$ & 2.098 & & 2.609 & & -0.112 & \\
\hline & $(0.728)$ & [2.88] & $(0.759)$ & {$[3.44]$} & $(0.842)$ & {$[-0.13]$} \\
\hline$U_{f t-j}$ & -0.075 & & -0.075 & & $\odot .119$ & \\
\hline & $(0.041)$ & {$[-1.80]$} & $(0.051)$ & {$[-1.48]$} & $(0.058)$ & {$[2.05]$} \\
\hline$U_{h t-j}$ & 0.236 & & -0.142 & & 0.124 & \\
\hline & $(0.050)$ & {$[4.68]$} & $(0.047)$ & {$[-3.05]$} & $(0.037)$ & {$[3.36]$} \\
\hline $\ln \left(\frac{A}{n}\right)$ & -0.015 & & -0.097 & & $\odot .059$ & \\
\hline & $(0.024)$ & {$[-0.610]$} & $(0.030)$ & {$[-3.17]$} & $(\odot .028)$ & {$[2.14]$} \\
\hline
\end{tabular}




$$
\begin{aligned}
& \begin{array}{llll}
\ln T_{t-j} & 0.014 & 1.525 & 0.663
\end{array} \\
& \left.\begin{array}{lccccc}
\ln \left(\frac{M X G}{T X G}\right)_{t-j} & (0.201)[0.069] & (0.256) & {[5.90]} & (0.297) & {[2.23]} \\
& 0.730 & -1.005 & -0.367
\end{array}\right] \\
& \begin{array}{llll}
\ln \left(\frac{R}{Y_{h}}\right)_{t-j} & 0.215 & -0.151 & 0.639 \\
& (0.116)[1.85] & (0.137)[-1.10] & (0.122)[5.26]
\end{array} \\
& R^{2}=0.996 \mathrm{~F}(23,10)=113.4[0.00]^{*} \quad \hat{\sigma}=0.079 \quad \mathrm{DW}=2.98 \\
& \text { RSS }=0.0626 \text { for } 24 \text { variables and } 34 \text { observations } \\
& F_{a r}(1,19)=6.48[0.03] F_{\text {arch }}(1,8)=0.75[0.59] \\
& \chi_{n d}^{2}(2)=4.46[0.11] F_{\text {reset }}(1,9)=0.16[0.71] \mathrm{T}=34(1971-2004)
\end{aligned}
$$

$R^{2}$ is the squared multiple correlation, $\hat{\sigma}$ is the residual standard deviation. The diagnostic tests are the form $F_{j}(k, T-1)$ which denotes an approximate $F$-test against the alternative hypothesis $j$ for: $k^{\text {th }}$-order serial correlation $F_{a r}$, Goldfrey (1978), $k^{\text {th }}$-order autoregressive conditional heteroscedasticity $F_{\text {arch }}$, Engle (1982), heteroscedasticity $F_{\text {hetero }}$, White (1980), the functional form RESET test $F_{\text {reset }}$, Ramsey (1969) and a chi-square test for normality $\chi_{n d}^{2}(2)$, Doornik and Hansen (1994). 

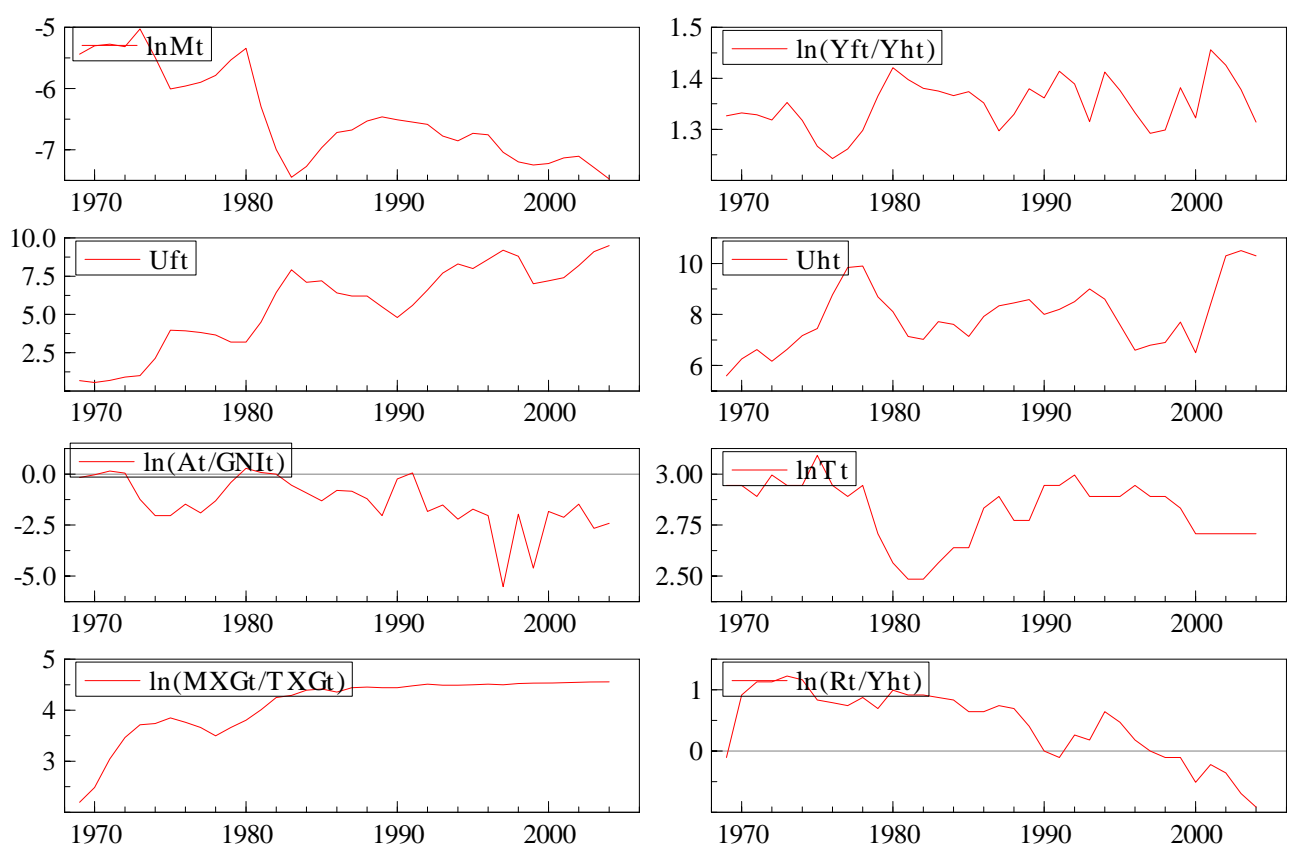

Figure 1: The basic properties of data: 1969-2004 

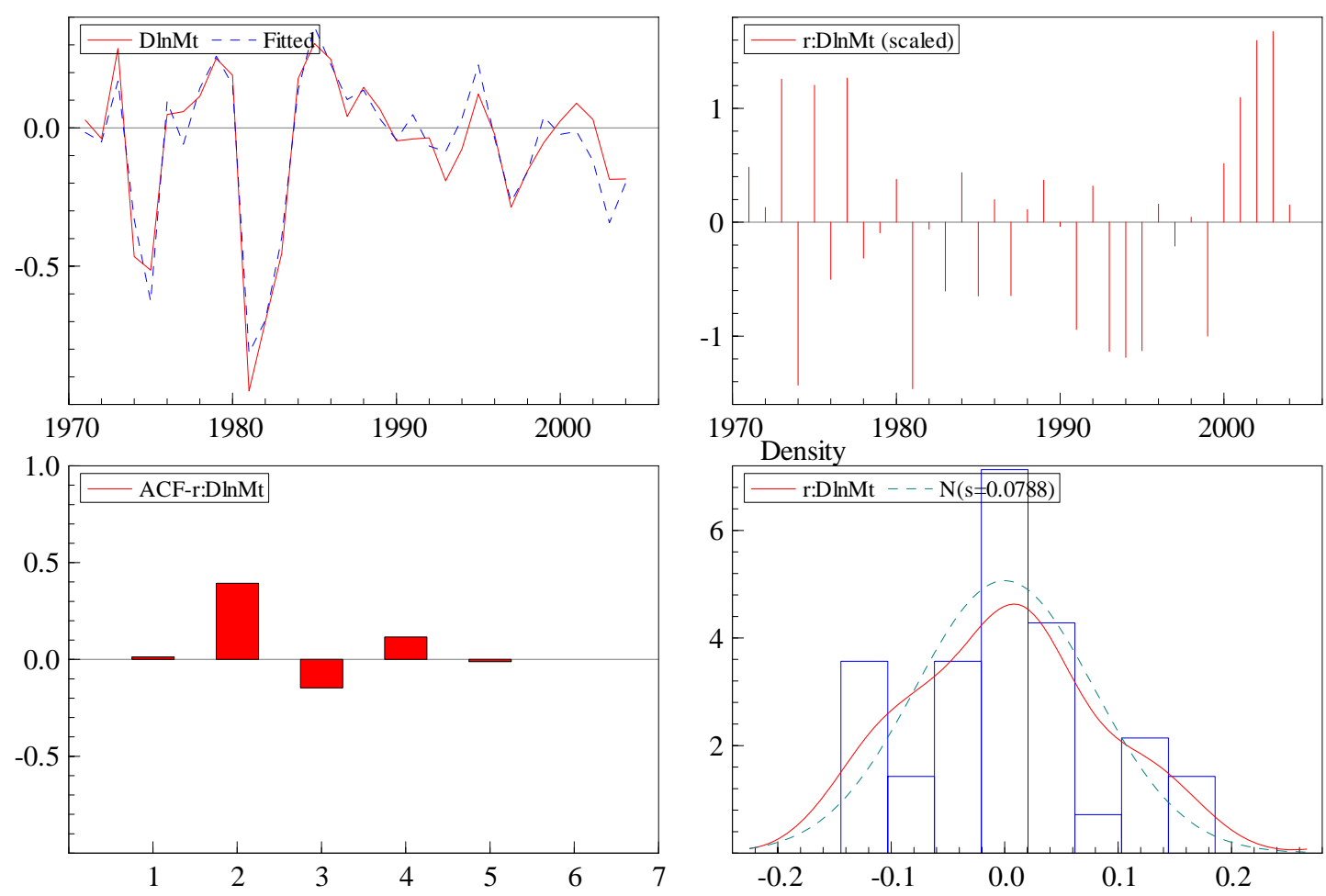

Figure 2: Actual and fitted values of migration model from Equation (4), residuals, the histogram and estimated density of the residuals and their correlogram. 

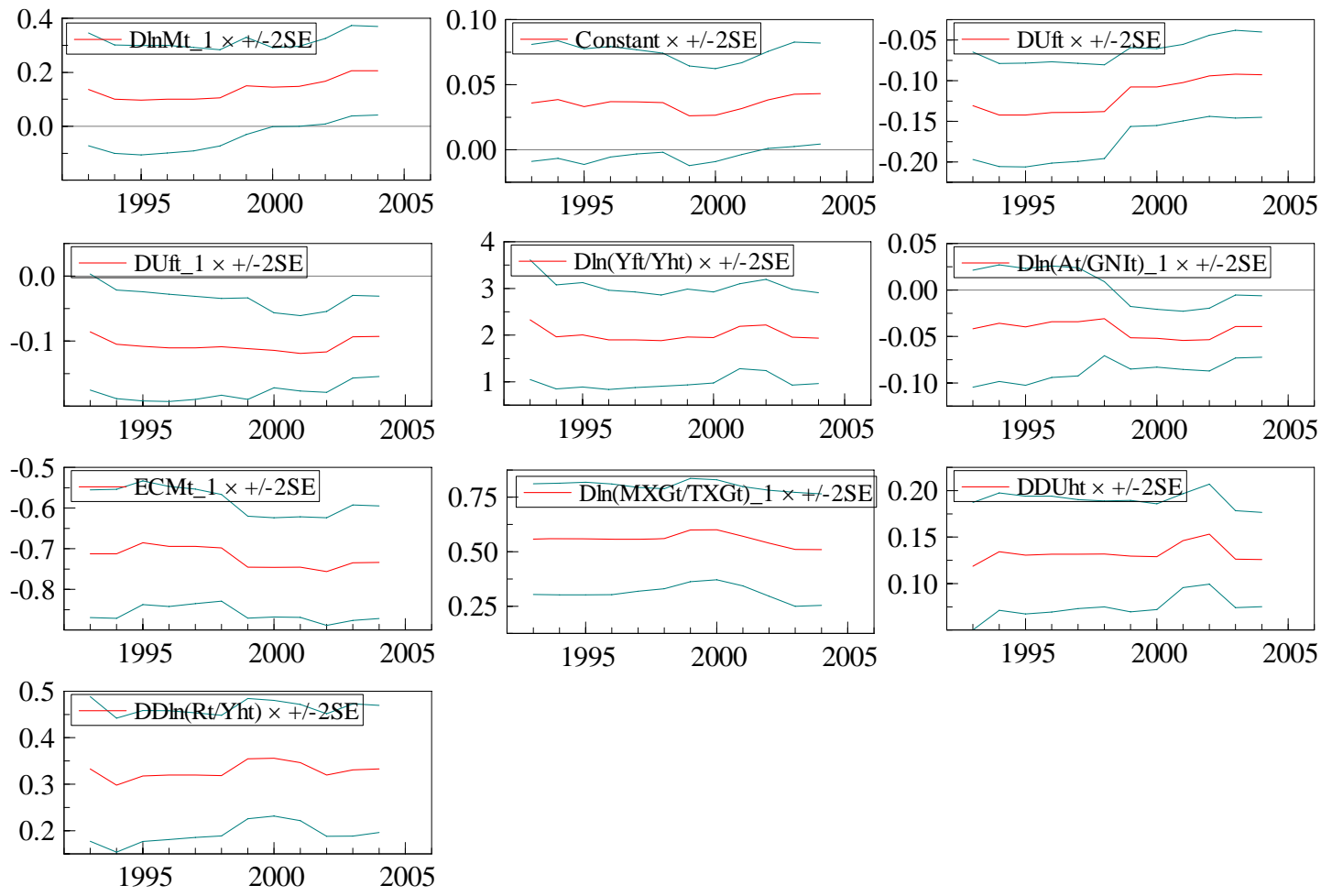

Figure 3: Recursive coefficients of consumption model (Equation 4) with \pm SE. 

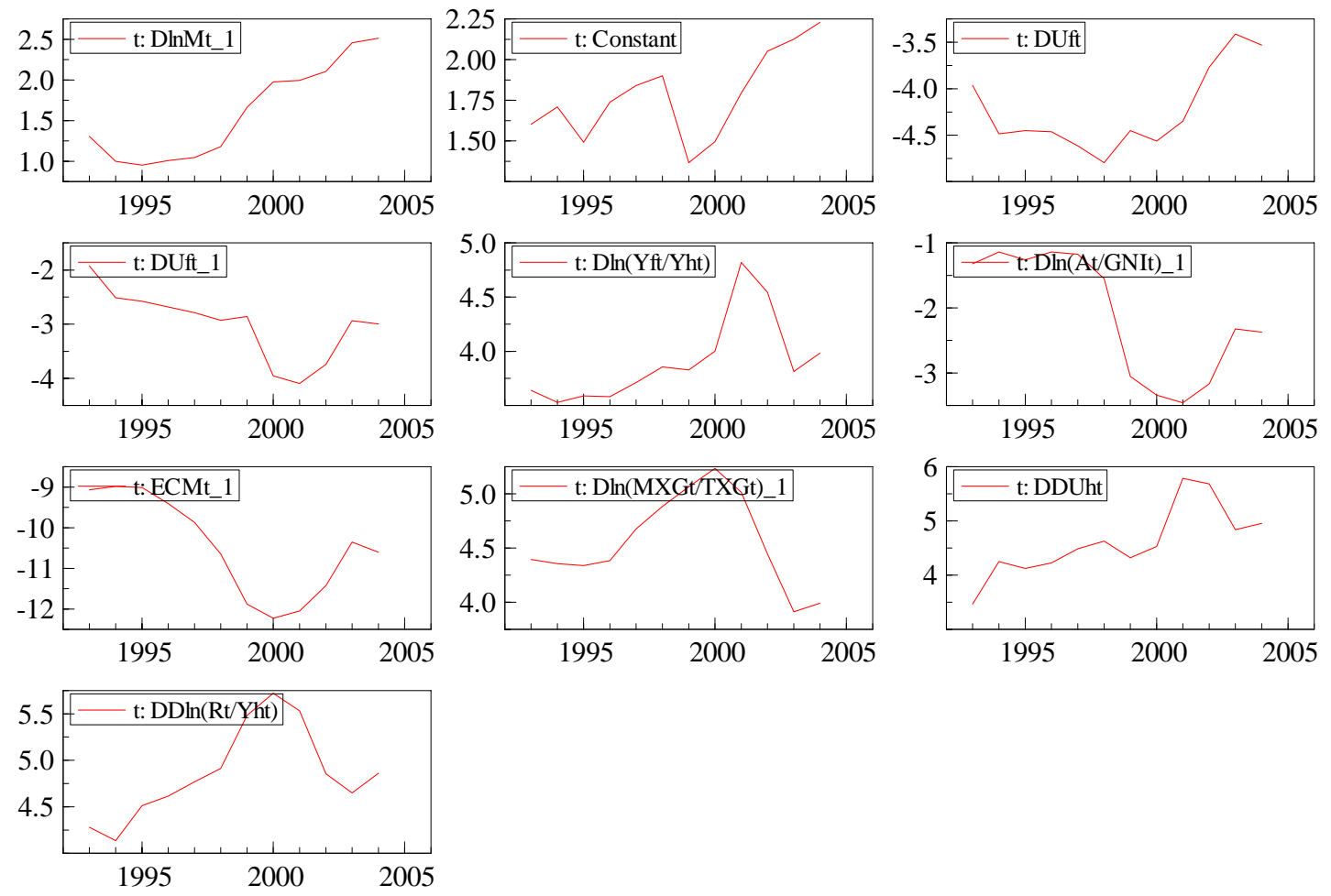

Figure 4: The recursive $t$-ratios. 

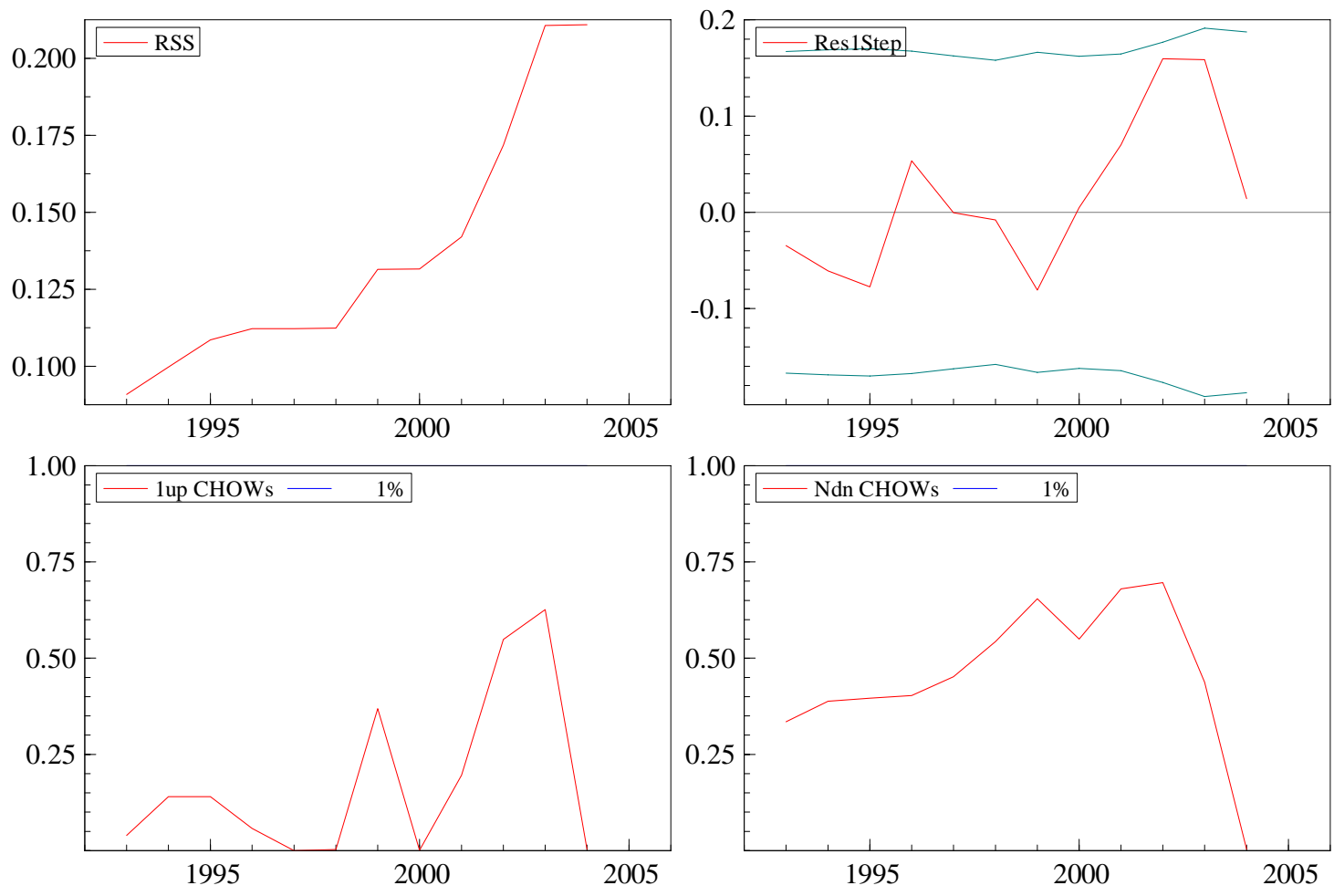

Figure 5: The residual sum of squares (RSS), one-step residuals and $0 \pm 2 \hat{\sigma}_{t}$, one-step Chow statistics and breakpoint Chow statistics. 